\title{
Investigation of Biomass Ash Properties for Their Utilization Assesment
}

\author{
Gotfrids Noviks \\ Rezeknes Augstskola, Faculty of Engineering, Department of Natural and Engineering Sciences \\ Address: Atbrivosanas aleja 76, Rezekne, LV-4601, Latvia.
}

\begin{abstract}
Ash is a mineral waste group, which quantity increases on a global scale and now it has achieved hundreds of millions of tons, and as they are an integral part of the any solid fuel, including biomass the production rate will continue. At the same time ash, due to their nature and composition is a unique material that can be valuable technogenic resource.

The paper studies the wood ash physical properties (density, porosity, specific free surface) composition and the metal adsorption ability. It was found that wood ash contains a significant percentage of metals in the mobile phase, which dissolve in the water and thus are able to spread into the surrounding soil. The study established a high adsorption activity of ash (95-99\%) to the metals. It was found that the adsorption capacity of the ash is possible to increase with the activation of the ash particle surfaces and changing the pore structure.
\end{abstract}

Keywords - biomass ashes, specific free surface, adsorption capacity, physical properties of ashes.

\section{INTRODUCTION}

Fuel contains the inorganic mineral components which after fuel combustion form ash. The quantity, composition, structure and properti of ash depend primarily on the fuel type and composition. Gaseous fuels practically does not have ash, fuel oil gives very little ash (depending on the type of fuel,for example, diesel $-0.01 \%$, oil- $0.15-0.3 \%$ ), soli fuel has the highest ash content fluctuation rang. The highest ash percentage have solid fossil fuels. A coal contain ash ranging from 2 to $50 \%$, lignite $-8-48 \%$, oil shale -50 $72 \%[1,2]$. Peat, which is located in the buffer zone between fossil fuels and biomass, has ash from even $1 \%$ (high peat bogs $-2-4 \%$ ) to $20 \%$ (low peat bogs 6 $18 \%)[3,4]$. As a result, the world eergy sector as well as all other sectors that use fuels formed large quantity of mineral waste - ash and disposal and managing of this volume is problem which solving has recently become acute. Thus, the Russian Federation is produced Thus, the Russian Federation is produced over $28,10^{6}$ tons of ash per year. Siberian Federal District have collected $300.10^{6}$ tons of unused ash.Statistical data. show that only the fly ash content in the world grows up $180.10^{6}$ tons per year [5].The use of Biomass - (wood, energy plants, straw, reeds) for heat production gives a much lower ash outcomefrom 0.5 to $12 \%$ depending on the types of plants and their growth conditions (wood-0,3-1,0\%, straw - 4.5 to $11.3 \%$ ) [6]. Thus, the transition to renewable energy sources - biomass seriously reduces the weight of the ash forming, but not solve the problem as a whole.For example, Finland in energy-use fuel - wood and peat annually produces $6.10^{5}$ tons of ash, but in general, the pulp and paper industry and other companies which use wood as fuel, this amount constitutes $1,02.10^{6}$ tons of ash per year. The same situation in Sweden $-8.10^{5}$ tons of wood ash per year. In the US. annually is produced approximately $3.10^{6}$ tons wood ash, in the China $-20.10^{5}$ t per year [7]. In the Latvia putting out timber volume consumed for heat generation and industrial technology and taking into account the average wood ash content around 3\% the annual production of ash is not less than 30000 tons. Consequently, the optimal utilization of ash is an essential to the Latvian conditions also, especially in view of the national and the EU's energy development strategy relating to the transition to renewable energy sources, including biomass. It is necessary to note that the solid organic waste for energy production gives the additional increase in the amount of ash. Also, from an environmental point of view and rational exploiting of resources it is important to find the optimal methods to utilize ash as technogenic resource [8].

Their composition, structure and properties are very diverse, and their use is therefore associated with the ash parameter studies[9,10,16,21,29].Ash utilization problems in the world are widely studied, the technology is put into practice. The main directions of ash application at the moment may be divided into 4 groups : agriculture, construction and building, production of materials, water purifying. These directions are summarized in the table below (Table $1)$. 
TABLE 1

ASH APPLICATION AREAS

\begin{tabular}{|l|l|l|l|}
\hline Agriculture[7,24,25,26] & Construction[12,15,17,20,23] & Material production[11,12,13,14,15] & Water treatment[18,19,32] \\
\hline 1.Mineral fertilizers for soil & 1.Binder & 1. Polyethylene filler & 1.Adsorbent \\
improvement & 2. Fiber cement & 2.Zeolite & 2.Electrocoagulation \\
2.Composting component & 3. Aerated cellular concrete & 3.Synthetic lightweight aggregates & optimization \\
3.Litter & 4. Bricks & 4.Rubber filler & 3.Neutralization \\
4.Sludge pasteurization & 5. Asphalt filler & 5.Phosphate ceramics & 4. Extraction \\
& 6. Road construction stabilization & 6.Inorganic fiber & 7. Vitrocrystalline materials \\
& & 8. Ceramicrete & \\
\end{tabular}

TABLE 2

\section{ELEMENT CONTENT IN ASH}

\begin{tabular}{|l|l|l|}
\hline $\begin{array}{l}\text { Chemical } \\
\text { element }\end{array}$ & $\begin{array}{l}\text { Content in wood } \\
\text { ashes, } \mathrm{C}_{\text {mas }} \%\end{array}$ & $\begin{array}{l}\text { Content in } \\
\text { coalashes, } \mathrm{C}_{\text {mas}}, \\
\%\end{array}$ \\
\hline $\mathrm{Ca}$ & $15(2,5-33)$ & $18(7-33)$ \\
\hline $\mathrm{K}$ & $2,6(0,1-13)$ & $1,6(3-4)$ \\
\hline $\mathrm{Mg}$ & $1,6(0,5-3,2)$ & $1,2(1-2)$ \\
\hline $\mathrm{Mn}$ & $0,4(0-1,3)$ & $1,2(0,3-1,3)$ \\
\hline $\mathrm{P}$ & $0,5(0,1-1,4)$ & $0,9(0,3-1,4)$ \\
\hline $\mathrm{Na}$ & $0,2(0-0,54)$ & $0,3(0,2-0,5)$ \\
\hline $\mathrm{N}$ & $0,15(0,02-0,8)$ & \\
\hline $\mathrm{Fe}$ & $2(1,6-2,45)$ & \\
\hline
\end{tabular}

TABLE 3

ASH CHEMICAL COMPOSITION IN TERMS OF OXIDES

\begin{tabular}{|l|l|l|}
\hline Oxides & $\begin{array}{l}\text { Contents in wood } \\
\text { ashes, } C_{\text {mas }}, \%\end{array}$ & $\begin{array}{l}\text { Content in coal } \\
\text { ashes, } C_{\text {mas }}, \%\end{array}$ \\
\hline $\mathrm{SiO}_{2}$ & $20-60$ & $40-70$ \\
\hline $\mathrm{Al}_{2} \mathrm{O}_{3}$ & $0,1-12$ & $14-35$ \\
\hline $\mathrm{Fe}_{2} \mathrm{O}_{3}$ & $1,5-5,3$ & $2-20$ \\
\hline $\mathrm{Fe}_{3} \mathrm{O}_{4}$ & - & $2-14$ \\
\hline $\mathrm{MgO}$ & $0,3-5$ & $1-10$ \\
\hline $\mathrm{Na}_{2} \mathrm{O}$ & $0,1-0,8$ & $0,1-5$ \\
\hline $\mathrm{CaO}$ & $0,8-43$ & $0,5-30$ \\
\hline $\mathrm{K}_{2} \mathrm{O}$ & $1-1,8$ & $0,5-3$ \\
\hline
\end{tabular}

TABLE 4

THE METAL CONTENT IN ASH

\begin{tabular}{|l|l|l|}
\hline Metal & $\begin{array}{l}\text { Content in wood } \\
\text { ashes,mg/kg }\end{array}$ & $\begin{array}{l}\text { content in } \\
\text { coal ashes, } \\
\mathrm{mg} / \mathrm{kg}\end{array}$ \\
\hline $\mathrm{Fe}$ & $5000-6000$ & $7000-160000$ \\
\hline $\mathrm{Zn}$ & $350-620$ & \\
\hline $\mathrm{Cu}$ & $87,8-127$ & \\
\hline $\mathrm{Cr}$ & $54-133$ & $2-1100$ \\
\hline $\mathrm{Pb}$ & $20-27$ & $4-230$ \\
\hline $\mathrm{Cd}$ & $3,5-4,9$ & $3-7$ \\
\hline
\end{tabular}

It can be seen that in the solid fossil fuel ash composition prevail silicon, aluminum, iron, while the biomass ash composition is characterized mainly with calcium, potassium, magnesium. Wood ashes observed significantly lower content of heavy metals $[8,9,22]$.

The specific direction of the ash application depends on the ash composition and structure. Thus, the ash being used in the production of adsorbents options determine the porosity, pore shape, size and structure, the specific free surface area, adsorption ability and capacity. The paper presents results of wood ash physico-chemical studies

\section{MATERIALS AND METHODS}

Object of research - wood ash, collected from firewood, consisting mainly of pine, birch wood mixture burned in private home furnaces. Ashes were dried to constant weight in a drying oven at a temperature of $115-120^{\circ} \mathrm{C}$ and screened out through a sieve with a mesh width of $0.5 \mathrm{~mm}$.

Weed out ash color was light gray with small black particles of unburned coal impurities.Experimentally determined ash characteristics:

1. Friable weight - by the direct weighing of the volume of ash, poured into a beaker. Mass of the samples were $20-40 \mathrm{~g}$.

2. Mineral mass density-with pycnometer method. Mass of samples were 2-3g.

3. Specific free surface - with methylene blue adsorption method, which is based on the Langmuir adsorption theory equation, which defines the relationship between adsorbed on the surface quantity of molecules mononuclear layer and the amount of the surface. The surface area of the adsorbent surface $S_{f}$, which holds the adsorbed molecules

$$
\mathrm{S}_{\mathrm{f}}=\mathrm{V} \cdot \mathrm{N} \cdot \mathrm{CA}_{\mathrm{m}} / \mathrm{m} \cdot \mathrm{M}
$$

Where:

$\mathrm{V}$ - volume of solution use for titration, $\mathrm{ml}$,

$\mathrm{C}$-concentration of the solution

$\mathrm{N}$-Avogardo's number

$A_{m}$-square,which occupies one molecule of the substance adsorbed on the adsorbent surface M-adsorbable substances molecular weight m- ash sample mass

In an experiment using methylen blue

$\mathrm{M}=319.9 \mathrm{~g}, \mathrm{Am}=106 \cdot 10^{-20}, \mathrm{~m}^{2}, \mathrm{C}=0.03 \mathrm{~g} / 1$,

$\mathrm{N}=6.023 .10^{-23}$.

The sample of the ash (about $1 \mathrm{mg}$ ) was poured in $25 \mathrm{ml}$ of water, then added the sulfuric acid - 5n concentration, mixed and then the suspension was 
titrated with $0.3 \%$ methylene blue according to the standard method [27].Specific surface area calculations were performed according to the formula

$$
\mathrm{S}_{\mathrm{f}}=5.98 \cdot 10^{3} \mathrm{~V} / \mathrm{m}, \mathrm{m}^{2} / \mathrm{g} \text {. }
$$

4. Loss on heating $\eta$ - by the direct weighing method. Samples $\left(\mathrm{m}_{0}=5 \mathrm{~g}\right)$ were heated in a muffle furnace at a temperature of $850-900{ }^{\circ} \mathrm{C} 2$ hours, and then weighed $\left(\mathrm{m}_{1}\right): \eta=\mathrm{m}_{0} / \mathrm{m}_{1}$

5. One of the most important characteristics of the ash is quantity and composition of soluble components in the ash[28]. The study determined experimentally ash component solubility changes depending on the time of contacting with water. Ash samples -6 portions each of the $10 \mathrm{~g}$ were tipped onto 6 glasses with distilled water $200 \mathrm{ml}$ and suspension was stirred in flocculation device "Armfield" 10, 20, $30,40,60,90$ minutes at a temperature of $20^{\circ} \mathrm{C}$ at a speed of 150 RPM. Solutions were filtered, and then were measured: optical density, electrical conductivity, $\mathrm{pH}$, phosphate, nitrate and nitrite contents.

Having regard to soil contamination with heavy metals profound impact on the quality of the environment and ecosystems in all filtrates were determined concentration of heavy metals - the moving soluble phase, which is able to migrate into the soil. Analyzes were performed with a Perkin Elmer atomic absorption spectrometer firm AAnalyst200.

In the ash samples after their flltration and drying was determined specific free surface.

In order to analyze the potential use of ash as adsorbents for wastewater treatment for all ash samples was determined adsorption capacity. For this purpose, the experimental solution was made with six metal ion content.In distilled water were dissolved 0.02 to 0.06 g salts $\left(\mathrm{CuSO}_{4}, \mathrm{FeSO}_{4}, \mathrm{MnSO}_{4}, \mathrm{CrCl}_{3}\right.$, $\mathrm{PbSO}_{4}, \mathrm{CoSO}_{4}$ ) so that the metal ions in solution should be between 2.5 and $4.5 \mathrm{mg} / \mathrm{l}$.

Adsorption ability was investigated as follows:In 7 flasks were poured $200 \mathrm{ml}$ of experimental solution, and $5 \mathrm{~g}$ of the ash samples. The flasks were placed on a rotary shaker for 1 hour. After the shaking solution was filtered and in the filtrate was determined the concentration of remaining metal by Perkin Elmer atomic absorption spectrometer AAnalyst200. Were calculated the absolute amount of adsorbed metal $\mathrm{m}_{\mathrm{ad}}$, solution concentration change $\Delta \mathrm{C}$, solution treatment of metals degree $\eta$ and the relative adsorption capacity of 1 gram of ash $A_{n}$.

\section{EXPERIMENTAL RESULTS}

The investigated wood ash mechanical and physical properties are summarized in the Table 5.

TABLE 5

MECHANICAL PROPERTIES OF WOOD ASH

\begin{tabular}{|c|c|c|c|}
\hline NR & PROPERTIES & RANGE & AVERAGE \\
\hline 1 & FRIABLE WEIGHT , G/CM ${ }^{3}$ & $0,50-0,59$ & 0,53 \\
\hline 2 & $\begin{array}{c}\text { MINERAL MASS } \\
\text { DENSITY } \mathrm{P}_{0}, \mathrm{G} / \mathrm{CM}^{3}\end{array}$ & $1,74-1,87$ & 1,82 \\
\hline 3 & $\begin{array}{c}\text { POROSITY IN LOOSE } \\
\text { PHASE P, } \%\end{array}$ & $68-72,3$ & 70,8 \\
\hline 4 & LOSS ON HEATING H, \% & $6,9-7,8$ & 7,75 \\
\hline 5 & $\begin{array}{c}\text { SPECIFIC FREE SURFACE } \\
\mathrm{S}_{\mathrm{F}}, \mathrm{M}^{2} / \mathrm{G}\end{array}$ & $2,2-2,4$ & 2,25 \\
\hline
\end{tabular}

Specific free surface of filtered ash after extraction of soluble substances is shown in the table 6 .

TABLE 6

\begin{tabular}{|l|l|l|l|l|l|l|l|}
\hline $\begin{array}{l}\text { Rinse } \\
\text { time,min }\end{array}$ & 10 & 20 & 30 & 40 & 90 & $\begin{array}{l}\text { Sinte- } \\
\text { red }\end{array}$ & $\begin{array}{l}\text { Heated } \\
\text { in } \\
\text { water }\end{array}$ \\
\hline $\begin{array}{l}\text { Specific } \\
\text { free } \\
\text { surface } \\
\mathrm{S}_{\mathrm{f}}\left(\mathrm{m}^{2} / \mathrm{g}\right)\end{array}$ & 2,9 & 2,3 & 2,4 & 2,9 & 2,2 & 2,2 & 9,6 \\
\hline
\end{tabular}

In the table 7 are results of the filtered ash adsorption efficiency to metals as changes of their concentration in the experimental solution after adsorption.

Adsorption rates were calculated as the concentrations ratio $\Delta \mathrm{C} / \mathrm{C}$. Table 8 summarizes the ash extract physico-chemical properties and Table 9 metal content of wood ash extracts depending on extraction time.

TABLE 7

ASH ADSORPTION EFFICIENCY (CONCENTRATION C, MG / L) TO METALS DEPENDENCE OF MIXING TIME.

\begin{tabular}{|l|l|l|l|l|l|l|l|l|}
\hline Metal & $\begin{array}{l}\text { Experimental } \\
\text { solution } \\
\left(\mathrm{C}_{0}\right)\end{array}$ & $10 \mathrm{~min}$ & $20 \mathrm{~min}$ & $30 \mathrm{~min}$ & $40 \mathrm{~min}$ & $90 \mathrm{~min}$ & $\mathrm{C}_{\text {avg }}$ & $\begin{array}{l}\text { Adsorption } \\
\text { rate, } \%\end{array}$ \\
\hline $\mathrm{Cu}$ & 2,84 & 0,12 & 0,14 & 0,12 & 0,14 & 0,13 & 0,13 & 95,4 \\
\hline $\mathrm{Co}$ & 2,62 & 0,0 & 0,01 & 0,0 & 0,006 & 0,0 & 0,003 & 99,9 \\
\hline $\mathrm{Cr}$ & 3,52 & 0,04 & 0,06 & 0,05 & 0,05 & 0,04 & 0,048 & 98,6 \\
\hline $\mathrm{Mn}$ & 3,87 & 0,01 & 0,016 & 0,013 & 0,02 & 0,006 & 0,013 & 99,6 \\
\hline $\mathrm{Fe}$ & 4,48 & 0,0 & 0,03 & 0,0 & 0,03 & 0,0 & 0,012 & 99,7 \\
\hline $\mathrm{Pb}$ & 2,37 & 0,007 & 0,035 & 0,17 & 0,02 & 0,01 & 0,018 & 99,2 \\
\hline
\end{tabular}


TABLE 8

THE PHYSICOCHEMICAL PROPERTIES OF ASH EXTRACT

\begin{tabular}{|l|l|l|l|l|l|l|l|}
\hline \multirow{2}{*}{ Properties } & \multicolumn{9}{|l|}{ Extract after the mixing, min } & $\begin{array}{l}\text { Heated in } \\
\text { water, } 60 \\
\text { min }\end{array}$ \\
\cline { 2 - 7 } & 10 & 20 & 30 & 40 & 60 & 90 & 0,646 \\
\cline { 1 - 7 } $\begin{array}{l}\text { Optical density A,\% } \\
, \lambda=350 \mathrm{~nm}\end{array}$ & 0,176 & 0,104 & 0,097 & 0,140 & 0,099 & 0,083 & \\
\hline$\lambda=760 \mathrm{~nm}$ & 0,019 & 0,003 & 0,006 & 0,019 & 0,006 & 0,04 & 0,015 \\
\hline $\begin{array}{l}\text { Electrical } \\
\text { conductivity 6,mS }\end{array}$ & 3,1 & 3,0 & 3,0 & 3,1 & 3,0 & 3,2 & 7,7 \\
\hline pH & 9,9 & 9,9 & 9,5 & 9,6 & 9,6 & 9,6 & 9,9 \\
\hline Nitrates, mg/l & 3,6 & 2,5 & 3,2 & 2,4 & 2,6 & 5,9 & - \\
\hline Nitrites, mg/l & 0,15 & 0,34 & 0,25 & 0,18 & 0,20 & 0,32 & - \\
\hline Phosphates , mg/l & 1,9 & 1,4 & 1,4 & 1,9 & 1,0 & 1,2 & - \\
\hline
\end{tabular}

TABLE 9

THE METAL CONTENT IN THE WOOD ASH EXTRACT

\begin{tabular}{|c|c|c|c|c|c|c|c|c|c|c|c|c|}
\hline \multirow{2}{*}{$\begin{array}{l}\text { Mixing } \\
\text { time, } \\
\text { min }\end{array}$} & \multicolumn{2}{|l|}{$\mathrm{Cu}$} & \multicolumn{2}{|l|}{ Co } & \multicolumn{2}{|l|}{$\mathrm{Cr}$} & \multicolumn{2}{|l|}{$\mathrm{Mn}$} & \multicolumn{2}{|l|}{$\mathrm{Fe}$} & \multicolumn{2}{|l|}{$\mathrm{Pb}$} \\
\hline & $\begin{array}{l}\mathrm{C}, \\
\mathrm{mg} / \mathrm{l}\end{array}$ & $\begin{array}{l}\mathrm{C}^{\prime}, \\
\mathrm{mg} / \mathrm{kg} \\
\text { ash }\end{array}$ & $\begin{array}{l}\mathrm{C}, \\
\mathrm{mg} / \mathrm{l}\end{array}$ & $\begin{array}{l}\mathrm{C}^{\prime}, \\
\mathrm{mg} / \mathrm{kg} \\
\text { ash }\end{array}$ & $\begin{array}{l}\mathrm{C}, \\
\mathrm{mg} / \mathrm{l}\end{array}$ & $\begin{array}{l}\mathrm{C}^{\prime}, \\
\mathrm{mg} / \mathrm{kg} \\
\text { ash }\end{array}$ & $\begin{array}{l}\mathrm{C}, \\
\mathrm{mg} / \mathrm{l}\end{array}$ & $\begin{array}{l}\mathrm{C}^{\prime}, \\
\mathrm{mg} / \mathrm{kg} \\
\text { ash }\end{array}$ & $\begin{array}{l}\mathrm{C} \\
\mathrm{mg} / 1\end{array}$ & $\begin{array}{l}\mathrm{C}^{\prime}, \\
\mathrm{mg} / \mathrm{kg} \\
\text { ash }\end{array}$ & $\begin{array}{l}\mathrm{C}, \\
\mathrm{mg} / \mathrm{l}\end{array}$ & $\begin{array}{l}\mathrm{C}^{\prime}, \\
\mathrm{mg} / \mathrm{kg} \\
\text { ash }\end{array}$ \\
\hline 10 & 0,077 & 1,54 & 0,032 & 0,65 & 0,223 & 4,46 & 0,012 & 0,24 & 0,058 & 1,16 & 0,018 & 0,37 \\
\hline 20 & 0,072 & 1,44 & 0,033 & 0,66 & 0,256 & 5,13 & 0,007 & 0,14 & 0,007 & 0,14 & 0,018 & 0,36 \\
\hline 30 & 0,113 & 2,27 & 0,053 & 1,06 & 0,259 & 5,17 & 0,018 & 0,37 & 0,003 & 0,06 & 0,018 & 0,36 \\
\hline 40 & 0,096 & 1,92 & 0,046 & 0,92 & 0,368 & 7,36 & 0,025 & 0,49 & 0,00 & 0,00 & 0,021 & 0,41 \\
\hline
\end{tabular}

\section{DISCUSSION}

From the literature data the properties of biomass ash are quite different, which means that each type of biomass, depending on the composition, growth conditions and possible burning regimes may have extensive property variation.

At the same time our experimental data show that the investigated wood ash density, friable weight, loss on ignition is possible properties within a fluctuation band: density range 1.7 to $1.9 \mathrm{~g} / \mathrm{cm}^{3}$ is also characterized by wood and other biomass ash.

Wood ash particles after screening were analyzed visually under a microscope and compared to paper and reed ash obtained in analogous burning conditions (Fig.1).

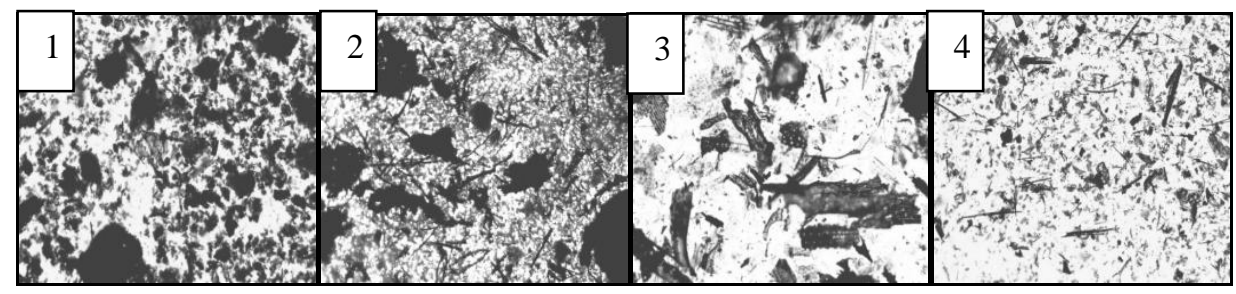

Figure1. Biomass ash under a microscope: 1 - wood ash, 2- reed ash,3-paper ash, 4 - reed ash heated at $9000 \mathrm{C}$

The images show significant differences in the structure of the ash. Wood ash particles have finer shape close to spherical, stick together in clusters.Reed ashes contain the unburned plant cells, the paper ash has more fibrous particles structure. It can be concluded that wood ash must have larger specific free surface, which determines the activity of contact with other substances to be higher.The measured wood ash free surface $S_{\mathrm{f}}$ average $2.4 \mathrm{~m}^{2 /}$ gis characterized by the ash of biomass and other fuels, for example the fly ash of coal and lignite ash have $S_{f}$ between 2.01 to $5.4 \mathrm{~m}^{2} / \mathrm{g}$ Typically, the ash specific free surface is independent of the flushing time of 1090 min range (table 6). This means that washing itself without temperature changes practically does not change the pore structure. 
Exposure to biomass ash activation can achieve much higher specific free surface values. Thus, as shown in the study [30], rice husk ash additional processing increases the specific surface of $119 \mathrm{~m}^{2} / \mathrm{g}$. Also, in our experiments ash samples, which were treated in hot water at $90^{\circ} \mathrm{C}$ increased the specific surface area of up to $9.6 \mathrm{~m}^{2} / \mathrm{g}$ (see the table 6). Typically, the only heating without the presence of water up to $900{ }^{\circ} \mathrm{C}$ show that specific surface area remained at $2.2 \mathrm{~m}^{2} / \mathrm{g}$ range.

As already mentioned the soluble component content in ash in many cases determines their using potential areas and restrictions.

This is especially important for heavy metal migration ability in soil from ash. A dangerous situation is possible not only when the ashes are used for improvement of soil, but also in emergency situations. In Greece performed studies of mobile metal ions from the ashes spread of forest fires and their impact on soil and ground water quality $[31,32]$

Given that in the Latvia quite extensively are burned in spring last year's litter, this question arises in our environment also.

Therefore, in our investigation in ash extracts were determined concentrations of heavy metals

Experiments showed that in the water from ashes were extracted copper, cobalt, chromium, manganese, iron and lead. (Fig.2, Fig.3, Fig 4.) In solutions were did not found nickel and cadmium.

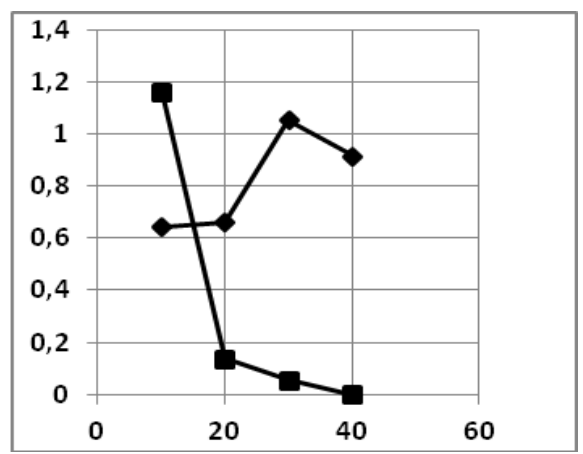

Figure 2. Cobalt and iron concentration $\mathrm{C}$ in the water changes depending on the ash flushing time $t$.

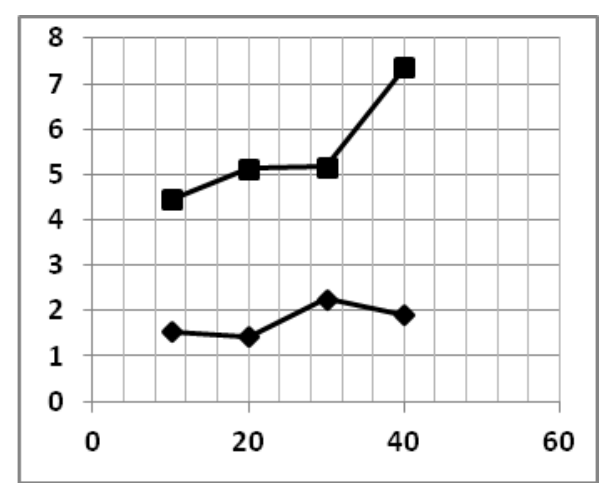

Figure 3. Chromium and copper concentration $\mathrm{C}$ in the water changes depending on the ash flushing time t.

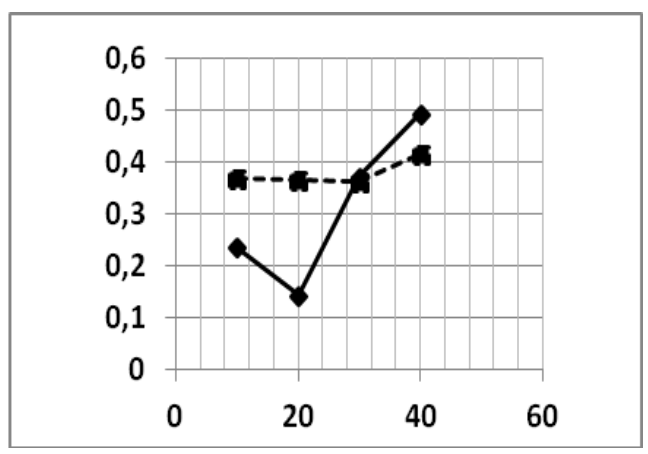

Figure4. Lead and manganese concentration $\mathrm{C}$ in the water changes depending on the ash flushing time $\mathrm{t}$.

In filtrate, where the ashes were heated in at $90{ }^{\circ} \mathrm{C}$, turned out to be significantly higher dissolved metal concentrations.

Thus, the copper concentration in the solution increased 1.27 times, the cobalt -1.73 , chromium 1.27, manganese-1.16 Iron-2.69 lead -1.9 times compared to the maximum concentration of extract at a temperature of $20^{\circ} \mathrm{C}$ (Fig.5).

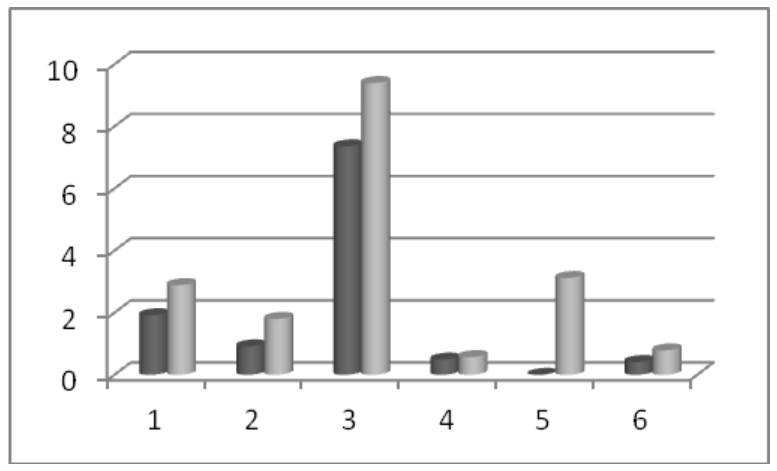

Figure 5. Metal concentration changes in water after heating to $90^{\circ} \mathrm{C}$ in water compared with rinsing at $\mathrm{T}=20^{\circ} \mathrm{C}$. 1 - copper, cobalt 2 3,4-chromium-manganese, 5 - iron, 6 - lead

In these circumstances the nickel $(\mathrm{C}=0.06 \mathrm{mg} / \mathrm{l})$ was found in solution also.

Substantial increasing all the dissolved elements concentrations in the hot water is also confirmed by the solution conductivity enlarging ( 2 times) and the optical density of high-frequency light wave range (3.7times) increasing.

In ash extracts were found phosphates, nitrates $\mathrm{NaNO}_{3}$ and nitrites $\mathrm{NaNO}_{2}$.Nitrate concentration greater than nitrite concentrations between 13 and 24 times (see table 8.). Typically, the mixing time did not affect significantly the concentrations of the substance, and did not change the $\mathrm{pH}$ of the solution (9.7), the specific electrical conductivity $(3 \mathrm{mS})$ and optical density. Ash adsorption capacity were investigated in all ash samples after washing - as a result of the ash were removed soluble components

Solution after the ash adsorption (table 9.) show that from the solution were adsorbed all metals. Extract metals constitute 95.4 to 99.9 percent. Parallel experiment showed that the ash flushing for at least 90 min did not give a significant change in the ash adsorption ability. 
But the ashes, which were previously subjected to heating at a temperature of $900^{\circ} \mathrm{C}$ per hour adsorption capacity increased with respect to all metals (Fig. 6).

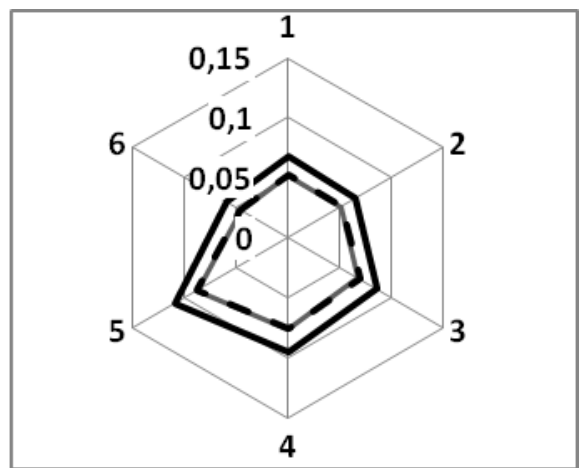

Figure 6. Ash adsorption capacity $(\mathrm{mg} / \mathrm{g}$ ) changes after heating at $900^{\circ} \mathrm{C}$ (solid line) compared with rinsing at $\mathrm{T}=20^{\circ} \mathrm{C}$ (dotted line) 1 - copper, 2-cobalt,3 -chromium,4-manganese, 5 - iron, 6 - lead

The obtained experimental data were converted to ash adsorption capacity $\beta$ - the adsorbed amount of metal per gram mass of ash.

Since on the ash surface in our case absorb all metals was calculated integral ash adsorption capacity for all six metals, which amounted to an average of $0.367 \mathrm{~g}$ of metal per 1 kilogram of ash (Fig7).

Note that the metal concentration in solution were relatively low and the total amount of adsorbed metal on ash did not reach maximum saturation. This means that the results

of adsorbent capacity are conditional, but they strongly characterize wood ash as perspective adsorbent.

Apart from the initial concentration of the elements in the experimental solution each metal adsorption capacity $\beta$ ratio to the metal $\lambda$

$\lambda=\beta / \mathrm{C}_{\mathrm{M}}=0,185$

This means that the degree of adsorption within the limits of the carried experiment data is constant and independent of the initial metal concentration

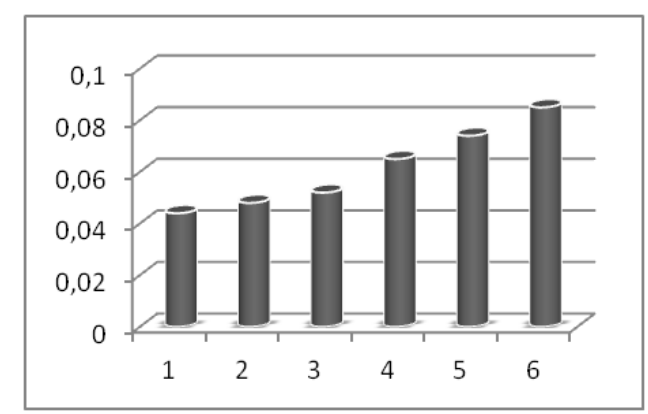

Figure 7. The average mass of the adsorbed metal by wood ash, mg / kg. 1 -lead,2-cobalt, 3-copper, 4-chromium, 5-manganese, 6-iron.

As was shown, ash specific free surface is relatively small in comparison with the specially designed adsorbent specific surface area. This means that despite the high adsorption capacity of the ash capacity is low. There is a need to continue research into the ash to increase the specific free surface and form a specific pore structure of the space optimally suitable physico-chemical adsorption smoothly

\section{CONCLUSIONS}

Researched wood ash mechanical and physical properties specific free surface, metal content of wood ash in extracts, ash adsorption capacity in connection with metals.

It was found that wood ash density is in the range of 1.74 to $1.87 \mathrm{~g} / \mathrm{cm}^{3}$, porosity $68-72 \%$ in loose phase. It is concluded that even at relatively low $-2.2-2.4 \mathrm{~m}^{2}$ / $\mathrm{g}$ specific surface free of ash adsorption capacity to metals $(\mathrm{Cu}, \mathrm{Co}, \mathrm{Cr}, \mathrm{Mn}, \mathrm{Fe}, \mathrm{Pb})$ is quite high. In the experimental solution after adsorption metal concentrations decreased by $95-99 \%$.

Part of metals in ash are in the soluble in water compounds. After stirring ash in water during10-90 $\min$ in the extracts were identified metals in concentrations comprised between 0,02 mg / 1 (Mn) up to $0.36 \mathrm{mg} / \mathrm{l}(\mathrm{Cr})$. Mixing time did not significantly increase concentrations of metals. The iron concentration in the extract even decreased to 0 after 90 minutes mixing time, which means that the iron changed in insoluble compounds. Cadmium and nickel were not found in the ash extracts. However, after heating the ash in water at $90^{\circ} \mathrm{C}$ gives a significant increase in metal ion solutions - an average of 1.2 to 2.7 times. In addition, in the solution appears nickel.

This means that each kilogram of ash can give in the groundwater up to $2 \mathrm{mg} \mathrm{Cu}, 7 \mathrm{mg} \mathrm{Cr}, 1 \mathrm{mg} \mathrm{Fe}$, less than $1 \mathrm{mg}-\mathrm{Pb}, \mathrm{Mn}, \mathrm{Co}$.

Experiments have shown that the ash specific free surface can be increased under pre-preparation, using physical effects to change the spatial pore structure and activate the particle surface adsorption capacity, such as when exposed to hot water.

It can be concluded that the ash is a perspective raw material for production adsorbents and their use have positive effect not only in the traditional farming areas, but is perspective in wastewater treatment technologies as well.

\section{REFERENCES}

[1] Jan Kalembkiewicz,Urszula Chmielarz, "Ashes from cocombustion of coal and biomass: New industrial waste", in Resources, Conservation and Recycling,vol. 69, December 2012, pp. 109-121

[2] Smriti Singh, Reginald E. Masto, Santosh K. Verma", A comparative evaluation of minerals and trace elements in the ashes from lignite, coal refuse, and biomass fired power plants", in International Journal of Coal Geology, Vol. 87, Issue 2, 1 August 2011, pp.112-120

[3] B.M. Steenari,S. Schelander, O. Lindqvist," Chemical and leaching characteristics of ash from combustion of coal, peat and wood in a $12 \mathrm{MW} \mathrm{CFB} \mathrm{-} \mathrm{a} \mathrm{comparative} \mathrm{study"} \mathrm{in} \mathrm{Fuel,}$ Volume 78, Issue 2, January 1999, pp. 249-258

[4] A.M. Grishin, A. N. Golovanov, Ya. V. Sukov, "Experimental study of peat ignition and combustion", in Journal of Engineering Physics and Thermophysics, May 2006

[5] Bahor, M.P.; McLaren, R.J.; Niece, J.E.; Pedersen, H.C., Coal ash disposal manual: second edition. Final report, EPRI-CS2049,1981Larry L. Baxter, "Ash deposition during biomass 
and coal combustion: A mechanistic approach" in Biomass and Bioenergy, Volume 4, Issue 2, 1993,pp. 85-102

[6] Misra M.K., Ragland K.W., Baker A.J. "Wood ash composition as a function of temperature furnace".in Biomass and Bioenergy 4 (2): 103rd doi: 10.1016/0961-9534 (93) 90032-Y,1993.

[7] Adrian K. James, Ronald W. Thring, Steve Helle and Harpuneet S. Ghuman, "Ash Management ReviewApplications of Biomass Bottom Ash", in Energies , 5 2012,pp.3856-3873.

[8] Mary B. Ogundiran, Joshua O. Babayemi, and Chima G. Nzeribe.Determination of metal content and an assessmentof the potential use of waste cashew nut ash (cnsa)as a source for potash production", in BioResources,6(1), 2011,pp.529-536.

[9] Xiao, Ruirui,Chen, Xueli'Wang, Fuchen,Yu, Guangsuo “ The physicochemical properties of different biomass ashes a different ashing temperature",in Renewable Energy: An International Journal, vol. 36 Issue 1, 2011,pp.244

[10] Vassilev, Stanislav V. Baxter, DavidAndersen, Lars K.Vassileva, Christina G. "An overview of the composition and application of biomass ash: Part 2. Potential utilisation, technological and ecological advantages and challenges", in Fuel., vol. 105, 2013,pp.19-39.

[11] Richard A.Kruger, Mark Hovy and David Wardle,"The use of fly ash fillers in rubber", International Ash Utilization Symposium, Center for applied energy research, University of Kentucky, paper \#72, 1999.

[12] Carlos Leiva, Luis F. Vilches, Xavier Querol, Jose Vale, Constantino Fernandez Pereira,'Use of zeolitised fly ash in fire resistant plates ",in World of Coal Ash, Kentucky, USA, May 7-10, 2007

[13] Xavier Querol,Juan C.Umana,Felicia Plana, Andres Alastuey, Angel Lopez-Soler, Alejandro Medinaceli, Antonio Valero, Manel J. Domingo, Ezequiel Garcia-Rojo, "Synthesis of zeolites from fly ash in a pilot plant scale. Examples of potential environmental applications, in International Ash Utilization Symposium, Center for applied energy research, University of Kentucky, paper \#12, 1999.

[14] Yoshitaka Ishikawa, "A study on a technology t produce inorganic fibers by melting coal ash".

[15] Ola C. Holmstrom and Christopher. Swan,"Geotechnical properties of innovative, synthetic lightweight aggregates" International Ash Utilization Symposium, Center for applied energy research, University of Kentucky, paper \#49, 1999.

[16] Joaquín Capablo, Peter Arendt Jensen, Kim Hougaard Pedersen, Klaus Hjuler, Lars Nikolaisen, Rainer Backman, and Flemming Frandsen,"Ash properties of alternative biomass", in Energy \& Fuels 23 (4), 2009,pp.1965-1976.

[17] Felix F. Udoeyo; Hilary Inyang; David T. Young; and Edmund E. Oparadu"Potential of wood waste ash as an additive in concrete" in Journal of Materials in Civil Engineering, Vol. 18, No. 4,, 2006. 605

[18] O. B. Orori, L. Etie' gni, K. Senelwa, M. M. Mwamburi, K. B. Balozi,G. K. Barisa and E. S. Omutange,"Electro-coagulation treatment efficiency of graphite,iron and aluminum electrodes using alum and wood ash electrolytes on a Kraft pulp and paper mill effluent",in Water science and technology 62.7, 2010 pp.1526-1535

[19] M. Ahmaruzzaman,"Role of fly ash in the removal of organic pollutants from wastewater'in Energy \& Fuels, 23 (3), 2009.pp.1494-1511

[20] Mario Berra, Giancarlo De Casa, Marcello Dell'Orso, Luigi Galeotti, Teresa Mangialardi, Antonio Evangelista Paolini, Luigi Piga,"Reuse of woody biomass fly ash in cement-based materials: leaching tests" in Recycling of Biomass Ashes, Springer, 2011 pp.132-146

[21] Ek.Serafimova, M.Mladenov,I.Mihailova,Y.Pelovski,"Study on the characteristics of waste wood ash", in Journal of the University of Chemical Technology and Metallurgy, 46,1, 2001, pp.31-3

[22] Guoliang Wang, Laihong Shen, and Changdong Sheng "Characterization of biomass ashes from power plants firing agricultural residues "in Energy \& Fuels 26 (1), 2012,pp.102111

[23] Wang, Shuangzhen,Miller, Amber,Llamazos, Emilio, Fonseca, Fernando,Baxter, Larry "Biomass fly ash in concrete: Mixture proportioning and mechanical properties" in Fuel. Vol. 87 Issue 3, 2008. pp.365-371.

[24] Vassilev,S.V., Baxter,D.,Andersen,L.K., Vassileva, C.G. Ān overview of the organic and inorganic phase composition of biomass", in Fuel , 2012,

[25] V.Čepanko, P.Baltrenas,'Investigation natural zeolite and wood ash effects on carbon and nitrogen content in grain residue compost", in Pol.J.Environ.Stud.,vol.20, No.6,2011, pp.1411-1418.

[26] Katja Schiemenz, Jürgen Kern, Hans-Marten Paulsen, Silvia Bachmann, Bettina Eichler-Löbermann" Phosphorus Fertilizing Effects of Biomass Ashes",in Recycling of Biomass Ashes, 2011, pp 17-31

[27] Graphite. Methods for determination of specific surface, GOST 13144-79

[28] Xavier Querol, Juan C. Umana, Andres Alastuey, Carles Ayora, Angel Lopez-Soler, Felicia Plana,'Extraction of major soluble impurities from fly ash in open and closed leaching systems", in International Ash utilization symposium, Center for applied energy research, University of Kentucky, paper \#11, 1999.

[29] Jaworek, Anatol Czech, Tadeusz Sobczyk, Arkadiusz T. Krupa, Andrzej“" Properties of biomass vs. coal fly ashes deposited in electrostatic precipitator"in Journal of Electrostatics., vol. 71 Issue 2, 2013,p.p.165-175.

[30] Tariq Mahmood, Salman Akbar Malik, and Syed Tajammul Hussain "Biosorption and recovery of heavy metals from aqueous solutions by eichhornia crassipes (water hyacinth) ash",in BioResources 5(2), 2010,pp.1244-1256.

[31] Stylianos Liodakis, Magdalini Tsoukala, Georgios Katsigiannis"Laboratory study of leaching properties of Mediterranean forest species ashes" in Water, Air, and Soil Pollution,vol. 203, Issue 1-4,2009, pp. 99-107

[32] Mika Nieminen, Sirra Piirainen, Mikko Moilanen,"Release of mineral nutrients and heavy metals from wood and peat ash fertilizers : Field studies in Finnish forest soils", in Scandinavian Journal of Forest Research, 20, 2005, pp.146153. 